Dhaka Univ. J. Biol. Sci. 24(2): 177-189, 2015 (July)

\title{
SPATIAL SOIL EROSION MODELING FOR SUSTAINABLE AGRICULTURE DEVELOPMENT USING REMOTE SENSING AND GIS TECHNOLOGY
}

\author{
Umesh K. MAndal ${ }^{1}$, Sukumar Dutta ${ }^{2}$, NAzma ${ }^{3}$, Md. Shahjahan Ali ${ }^{2}$, \\ N.H. SharifeE ${ }^{2}$ AND Ashfaque AHMED* \\ Department of Botany, University of Dhaka, Dhaka-1000, Bangladesh
}

Key words: Spatial soil erosion, Ecological degradation, Remote sensing

\begin{abstract}
Middle mountain areas of Nepal Himalaya is seriously suffering from ecological degradation and an estimation of over 240 million cubic meter of top soil is being eroded annually to the Bay of Bengal. Thirteen per cent of Nepal's watershed area have deteriorated seriously and 10,000 sq $\mathrm{km}$ are devoid of sufficient vegetation. Top soil loss from the mountain results in the riverbeds' raise at a annual rate of $15-30 \mathrm{~cm}$ and its effect on soil fertility declines. Considering this, an attempt was made to estimate the soil loss using GI Science technology and its correlative interpretation with land system units and land use and cover types from Maheshkhola watershed. Among several empirical and physically-based erosion models, Revised USLE (RUSLE) using RKLSCP was used to estimate the soil loss in the present analysis. A total of 231,155 ton soil was estimated annually being lost from Maheshkhola watershed. Erosion rates were found highly associated with the slope of land system units. Thirty three per cent of the total soil loss were mainly contributed only by each land system units, 11 and 12. Depositional dissected alluvial fan was found highest of 3.62 $\mathrm{t} / \mathrm{ha} / \mathrm{yr}$ soil loss among the averages. Agriculture as a dominant human activity, spatially concentrated in $61.53 \%$ of the watershed area, was contributing significantly as of $90 \%$ of the total soil loss in the study area. Similarly soil cliff/landslide and river sand areas contributed $10.11 \mathrm{t} / \mathrm{ha} / \mathrm{yr}$ and $9.38 \mathrm{t} / \mathrm{ha} / \mathrm{yr}$ on an average, respectively. The land units, steeply mountainous terrain having soil loss more than $35 \mathrm{t} / \mathrm{ha} / \mathrm{yr}$ must be given higher priorities for soil conservation.
\end{abstract}

\section{Introduction}

Ecological degradation has been increasing in Nepal to the point where it has been estimated that over 240 million cubic meter of top soil is being eroded annually from the hills of Nepal majority of which ultimately reached to the Bay of Bengal through India and Nepal. Thus it is a common concern of these countries that needs a trans boundary

*Author of correspondence: <aashfaque67@yahoo.com>. ${ }^{1}$ Central Department of Geography, Tribhuvan University, Kirtipur, Kathmandu, Nepal. ${ }^{2}$ Bangladesh Space Research and Remote Sensing Organization (SPARRSO), Bangladesh. ${ }^{3}$ Local Government Engineering Department (LGED), Agargaon, Dhaka, Bangladesh. 
management. According to a nationwide inventory of watershed conditions, $13 \%$ of Nepal's land area has deteriorated seriously and 10,000 sq $\mathrm{km}$ are devoid of sufficient vegetation and are in danger of desertification ${ }^{(1)}$. Top soil lost from the mountain is raising the riverbeds in the Tarai at an estimated annual rate of $15-30 \mathrm{~cm}$. It increases the incidence of floods and reducing the fertility of fertile lands, damaging irrigation channels, dams and hydro-power projects. Soil loss from cultivated and grazing land is a major factor in decline of soil fertility. About 1.8 million tons of plant nutrients are being removed through crop harvesting ( 0.5 million tons) and soil erosion process ( 1.3 million tons). Only 0.3 million tons (16\%) are replenished by organic and mineral fertilizer sources( $^{(2)}$.

Soil degradation, one constituents of ecological degradation is recognized as a serious problem in Nepal because it is effecting more than 80 percent and as terrain is rugged and characterized by unstable and steep slopes making it vulnerable to exogenous factors, landslide and soil erosion ${ }^{(3)}$. The rapid growth of human and livestock population is putting severe pressure on natural resources especially on soil. The decline of soil fertility through topsoil erosion is one of the major ecological crises in agricultural and grazing lands. Soil management programs have an important role to play in this area. Surface erosion is less conspicuous than mass wasting, but it is much more damaging to the livelihood of Nepalese people. Many of men's activities cause the soil to become less protected than it would be in a natural state. The loss of one or two $\mathrm{mm}$ of topsoil every year may not make spectacular visual impact, but cumulative effect is the impoverishment of the soil base. Topsoil having highest level of nutrients is more productive for plant growth than lower horizons. Top soil erosion is threatening the soil fertility of many rainfed agricultural fields in the middle mountains of $\mathrm{Nepal}^{(4)}$.

Erosive rainfall, vegetation cover, soil erodibility, topography and protection measures are determining factors for estimation of soil loss. In the last 60 years, empirical, conceptual or physically based models have been built including former models of USLE $(5,6)$, MUSLE(7), SLEMSA(8), RUSLE(9,10) latter models of $\operatorname{WEPP}^{(11)}$, EUROSEM $^{(12)}$. These models were used in order to represent and to quantify the process of detachment transport and deposition of eroded soil with the aim of implementing assessment tools for either scientific or planning purposes.

The most common models used in Nepal are MMF (1984) in Middle Mountain(13), RUSLE in Bhote Koshi catchment, Nepal Himalaya ${ }^{(14)}$, RUSLE and RMMF in Kalchi Khola in mountaneous watershed.

Even though, a number of parametric models for predicting soil erosion exist, this study explores potential application of Revised Universal Soil Loss Equation (RUSLE) based on the integration of remotely sensed data and GIS for the central hill region of Nepal. RUSLE uses the same empirical principles as the USLE but includes improved rainfall erosivity factor incorporation of the influence of profile convexity/concavity 
using segmentation of irregular slopes and improved empirical equation for computing slope factor (LS). The objective of the present study is to estimate the soil loss in Maheshkhola watershed of central hill region of Nepal using Revised Universal Soil Loss Equation (RUSLE) through the application of remotely sensed data and GIS.

\section{Materials and Methods}

The study was conducted in Maheshkhola watershed, central hill region of Nepal. The total geographical area covered is $283.61 \mathrm{sq} \mathrm{km}$. (28361.0 ha). Geometrically, the location of the study area ranges from $84^{\circ} 57^{\prime} 30^{\prime \prime} \mathrm{E}$ to $85^{\circ} 15^{\prime} 00^{\prime \prime} \mathrm{E}$ and $27^{\circ} 37^{\prime} 30 \mathrm{~N}$ to $30^{\circ} 48^{\prime}$ $30 " \mathrm{~N}$ and bounded by lesser Himalayas in north, Siwalik range in south and Bagmati watershed in the east. In altitude, the study area ranges from $428 \mathrm{~m}$ above mean sea level in Galchi of Dhading district in the north west to $2484 \mathrm{~m}$ in Bhangkhoria of Makwanpur district in the south east ${ }^{(15)}$. The location of study area is shown in Fig. 1.

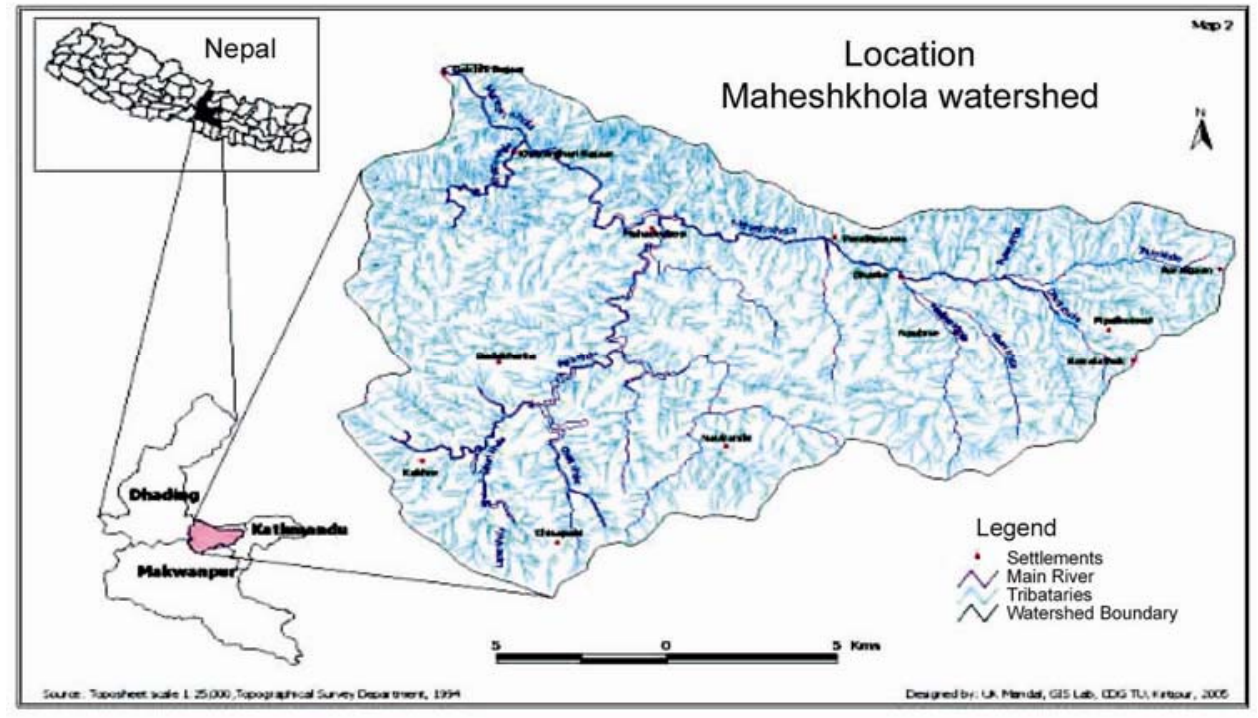

Source: Toposheet, $1996^{(16)}$.

Fig. 1. Map of location Maheshkhola watershed.

The climate varies from subtropical in the main valley and foot slopes through warm temperate at mid-elevations to cold temperate in the higher mountain ridge. In the lowlands, average summer temperature is $26.21^{\circ} \mathrm{C}$ with hotter months from April to September and average winter temperature is $18.37^{\circ} \mathrm{C}$. At higher elevations, average summer temperature is $16.78^{\circ} \mathrm{C}$ and average winter temperature is $9.56^{\circ} \mathrm{C}$. Annual precipitation also varies according to elevation changes, from $1694.75 \mathrm{~mm}$ in the lowlands to $1778 \mathrm{~mm}$ at higher elevations . Most of the rainfall occurs during the months of May to September ranging from 165 to $242 \mathrm{~mm}$ at highest of $462 \mathrm{~mm}$ in July. 
Geologically, the study area consists of a complex of phyllites, quartzites, schists, of Precambrian to Eocene age and limestone and gneiss of different ages. Phylites are often deeply weathered, reflecting their more stable landscape position, low bedrocks competence, and their highly fractured nature. Geomorphically, the area is characterized by alluvial plain to very steeply slopping mountaineous terrain. Among the tributaries as Naubise, Rupse, Dhuni and Thulo. Maheshkhola, Agra Khola is the main tributary of Maheshkhola watershed.

At higher elevations, land cover is dense mixed forest which mainly consists of chir pine (Pinus roxburghii) and broad leaf trees (Schima wallichii). In the cultivated areas, rainfed maize and millet are grown. At lower altitudes among open mixed forest, Sal (Shorea robusta) dominates and rice and rainfed maize and millet are the crops grown.

USLE developed by Wischmeier and Smith(5,6) with USDA, ARS and SCS in late 1950 and revised in 1978, is a powerful tool widely used by soil conservationists in the United States and many other countries. The USLE/RUSLE is an equation of estimating average annual soil loss by sheet and rill erosion on those portions where erosion, but not deposition is occurring. It does not estimate deposition at the toe of concave slopes, and not estimate sediment yield at a downstream location by not including ephemeral gully erosion. It also does not represent fundamental hydrologic and erosion processes explicitly ${ }^{(9)}$. The application of USLE/RUSLE as a tool to assist soil conservationists in farm planning by estimate of soil loss on specific slopes in specific fields. Thus, the USLE/RUSLE helps to tailor erosion control practices to those specific sites where soil

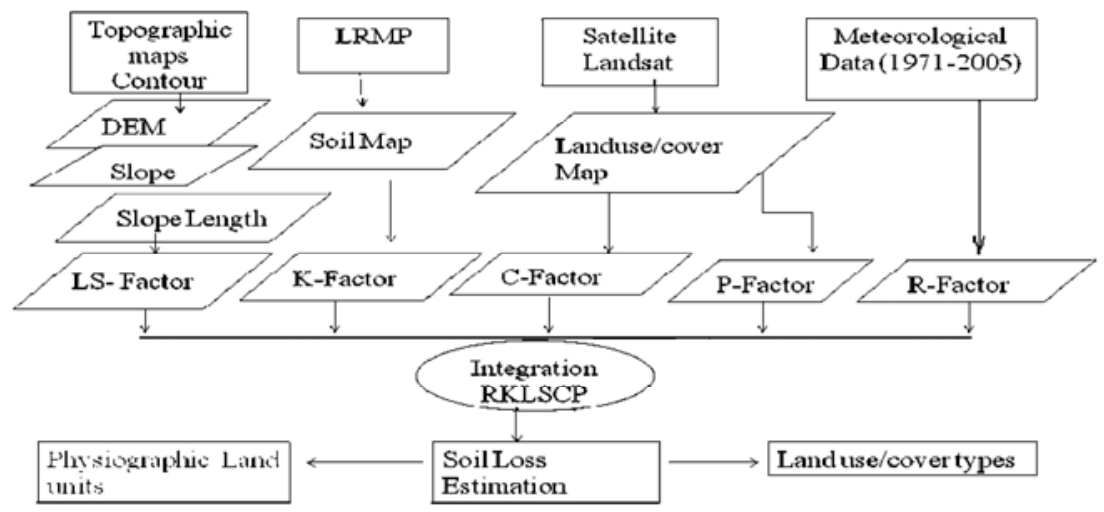

Fig. 2. Conceptual framework for soil loss estimation.

loss exceed acceptable limits and then it guides the conservationist and farmer in choosing a appropriate practices controlling erosion adequately while meeting the needs and wishes of the farmer. The conceptual framework and the major parameters such as rainfall erosivity (R), soil erodibility (K) (Table 1), slope steepness and length (LS), crop management factor $(\mathrm{C})$, erosion control practice factor $(\mathrm{P})$ associated with the soil loss estimation are shown in Fig. 2 and its explanation. 
Soil loss is related to kinetic energy of rainfall through the detachment power of raindrops striking the soil surface and the entrainment of the detached soil particles by run-off water down the slope. The kinetic energy of rainfall is dependent on annual rain and rainfall intensity. For annual rain, rainfall data were collected during 35 years period (1971 - 2005) of seven stations located inside and the vicinity of Maheshkhola watershed. Assuming that no rain shadow area exists in the watershed, a regression analysis of annual rainfalls with different elevations can be performed and if the correlation coefficient is found to be significant and high enough, an equation can be derived to compute rainfall map from elevation data ${ }^{(17,18)}$. Twenty $\mathrm{m}$ contour intervals and spot height from a topographic base map was used to generate digital elevation model (DEM) by interpolation procedure.

In Maheshkhola watershed, significant correlation coefficient at 95 percent confidence level was found between annual rainfall and elevation $(r=0.6)$ and thus used to generate a rainfall map using regression equation as follows:

$$
\mathrm{E}=1259+0.472 * \mathrm{DEM}
$$

Rainfall erosivity factor $(R)$ is based on kinetic energy considerations of falling rain and represents a measure of the erosive force and intensity of rain in a normal year (Goldman et al. 1986). Two components of the factor are the total energy (E) and the maximum $30 \mathrm{~min}$ intensity of storms $\mathrm{I}^{30^{(6)}}$. The R-factor is the sum of the product of these two components for all major storms in the area during an average year. Even though EI30 is the most reliable source for computing $R$, other equations might be used where $\mathrm{E}$ and $\mathrm{I} 30$ were not available. $\mathrm{R}=38.5+0.35 \mathrm{P}(\mathrm{P}=$ Mean annual precipitation) giving acceptable erosivity index for tropical and subtropical ecological zone is one of them. $\mathrm{R}=\left(9.28^{*} \mathrm{P}-8.8838\right)^{*} 0.102^{*} \mathrm{I}_{30} / 173.6^{(19)}, \mathrm{R}=0.0483^{*} \mathrm{P}^{1.61}$ when $\mathrm{P}<850 \mathrm{~mm}$ and $\mathrm{R}=587.8-1.219^{*} \mathrm{P}+0.005105^{*} \mathrm{P}$ when $\mathrm{P}>850 \mathrm{~mm}{ }^{(20)}$ are generally accepted equations for the mountainous tropical climate.

Rainfall intensity is an essential component for assessing soil erosion, since splash detachment is a function of rainfall energy, soil detachability and rainfall interception by crops. Rainfall showers less than $12.5 \mathrm{~mm}$ in a given days are assumed too small to have practical significance and are not considered as erosive ${ }^{(5,6)}$. But such interval of rainfall is not available from recorded stations. In this study, average rainfall intensity has been used in the following equation for estimation of R-factor:

$$
\mathrm{R}=\mathrm{E}(11.87+8.73 \log 10 \mathrm{I})
$$

where $\mathrm{R}=$ Rainfall erosivity $\left(\mathrm{J} \mathrm{m}^{2}\right) \mathrm{E}=$ Annual rainfall $(\mathrm{mm}), \mathrm{I}=$ Rainfall intensity $(\mathrm{mm} / 24 \mathrm{hrs})$ obtained from total amount of rain divided by number of rainy days of the stations located in and around the watershed.

Soil erodibility $(\mathrm{K})$ defines the inherent resistance of the soil to both detachment and transport that is influenced by soil structure, organic matter content, soil texture and soil permeability, it should be based on measured value wherever possible. Soil texture, 
structure, permeability and organic matter content are parameters that can be obtained from soil profile descriptions, and $\mathrm{K}$ values were also estimated from soil erodibility nomograph for those cases silt fraction does not exceed $70 \%(5,6)$ derived from the equation below $\mathrm{k}=\left(2.1 \times 10^{-4}(12-\mathrm{O} . \mathrm{M} \%)(\mathrm{N} 1 \times \mathrm{N} 2)^{1.14}+3.25(\mathrm{~S}-2)+2.5(\mathrm{P}-3)\right) / 100 \mathrm{O} . \mathrm{M}$. $=$ Organic Matter Content, N1 $=\%$ Silt $+\%$ Fine Sand, N2 = \%Silt $+\%$ Fine Sand + \%sand, S $=$ Level of Soil structure = Permeability, The $\mathrm{K}$ value can be calculated with the use of nomograph, derived by Wischemier and Smith ${ }^{(5,6)}$, when all the values of $\mathrm{K}$ influencing factors are available. In this study area, the soil parameters used are based on the average values of the laboratory data from the soil samples obtained from Land System Report. The soil detachability index $(\mathrm{K})$ is based on the value suggested soil parameters ${ }^{(18)}$ and given in Table 1. In general terms, the less the proportion of sand or silt, the higher the organic matter content, the more developed the soil structure, and the higher infiltration rate, the less erodible the soil will be ${ }^{(21)}$.

Lack of detailed soil map in Nepal forced to use data from The Soil Landscape of Nepal (21). Five samples based on land units were taken evenly distributed over existing soil series across the watershed. A polygon vector file of the physiographic soil map was used to generate K-value map using relationship with soil texture given in Table 1 . The soil detachability index value used for soil loss estimation is obtained from literature of Morgan Table that is based on proportion of clay percentage.

The potential for surface soil erosion will increase as the topographic factors, slope steepness and length are steeper and longer, respectively. The higher the velocity and greater the concentration of water, greater will be the erosion. Thus the slope factors are key component for estimating soil erosion hazard. The factors of slope length (L) and slope steepness (S) are combined in a single topographic index termed as LS factor.

Table 1. Soil parameters used for estimation of K-value ${ }^{(18)}$.

\begin{tabular}{lc}
\hline $\begin{array}{l}\text { Surface } \\
\text { texture }\end{array}$ & $\begin{array}{c}\text { Soil detachability } \\
\text { index }\end{array}$ \\
\hline Coarse texture (less than 15\% clay: sandy loam, loam) & 0.3 \\
Medium texture (less than 35\% clay: loam, sandy clay loam, silty clay loam) & 0.4 \\
Fine texture (more than 35\% clay: silty clay, sandy clay) & 0.4 \\
\hline
\end{tabular}

Wischmeier and Smith defined the slope length as the distance from the point of origin of overland flow to the point where either the slope gradient decreases enough that deposition begins or the runoff water enters a well-defined channel that may be part of a drainage network or a constructed channel. Slope steepness in percentage for the present watershed was derived from digital elevation model $(\mathrm{DEM})$ Slope $=(\mathrm{hyp}(\mathrm{dx}, \mathrm{dy}) / \mathrm{pixel}$ size $)^{*} 100$ and slope length was estimated by the relationship as : $L=0.4^{*} S+40$. 
The original USLE formula for estimating the LS factor was used for slope steepness up till $21 \%$. The equation is:

$$
\mathrm{SL}=(\mathrm{L} / 72.6)^{*}\left(65.41^{*} \sin (\mathrm{S})+4.56^{*} \sin (\mathrm{S})+0.065\right)
$$

The Gaudasasmita equation given below was used for the slope steepness of $21 \%$ or more:

$\mathrm{SL}=(\mathrm{L} / 22.1)^{0.7 *}\left(6.432^{*} \sin \left(\mathrm{S}^{0.79}\right)^{*} \cos \mathrm{S}\right)$

Where, $\mathrm{SL}=$ Slope length and slope steepness factor, $\mathrm{L}=$ slope length, $\mathrm{S}=$ slope steepness

Finally, topographic factor was generated by combing maps derived from eq.1 and eq. 2.

The ratio of soil loss under given crop to that from bare soil is represented as crop management factor $(\mathrm{C})$. The $\mathrm{C}$ factor combines plant cover, its production level and the associated cropping techniques. It varies from 1 on bare soil to 1/1000 under forest, 1/100 under grasslands and cover plants, and 1 to 9/10 under root and tuber crops. Knowing the land use, its value can be simply obtained from published tables. So, in the simplest form, as in the USLE, the $C$ factor is estimated based on the land use categorization of the concerned area. But in RUSLE, this factor is greatly revised and is estimated with the soilloss ratio (SLR) algorithm which incorporates several sub factors like prior-land-use (PLU), canopy-cover (CC), surface-cover (SC), surface-roughness (SR), and soil-moisture $(\mathrm{SM})^{(22)}$. Indirectly through the vegetation parameters like normalized difference vegetation index (NDVI) or leaf area index(LAI) as used for estimation of C-factor ${ }^{(23)}$. In order to determine $C$ factor in Maheshkhola watershed, supervised classified land use map generated from integrated use of Landsat ETM + images (2001), aerial photographs and toposheets was used. C-values used in this analysis were defined 0.004 for dense mixed sal forests, 0.02 for bush land and grass lands, 1 for bare land and 0.377 for agriculture land as recommended by Morgan et al. (12). $^{(2)}$

The P-factor mainly represents how surface conditions affecting flow paths and flow hydraulics. This factor is a ratio between erosion occurring in a field treated with conservation measures and another reference plot without treatment. Therefore, erosion control practice factor is based on the soil conservation practices such as contouring operated in a particular area. Details of procedure of calculation are obtained from Agricultural Handbook $703^{(9)}$. But practically the data of the adopted erosion control practices in the agricultural area are, in general, ranging from 1 for non-agriculture assuming that no conservation measures are implemented to 0.5 for agriculture land and its further redistribution spatially among different slope categories: 0.1 for 0 - 5\% to 0.33 for $50-100 \%$ (6) and accordingly, p value map was generated. 


\section{Results and Discussions}

The soil loss in Maheshkhola watershed was determined or estimated by crossing all factor value maps: R, K, LS, C and P explained above using RUSLE model in Integrated Land and Water Information System (ILWIS) GIS software. It is also called spatial analysis. The results of soil loss estimation derived from above process were presented and discussed in two ways of analysis units: physiographic land units and land use and cover types as below.

A total of 2, 31,155 ton soil is estimated using RUSLE annually being lost from the watershed. The mean annual soil loss estimated for the study area was found of 9.12 ton/ha/yr. Based on the erosion rates, the study area was classified into seven erosion classes ranging from 0.01 to 60.19 ton/ ha/yr (Table 2). $49.55 \%$ of watershed area is fallen within the second category of class with erosion rates ranging from 1.0 to 5.0 ton/ha/yr. Even though, the average erosion rate seemed to be higher as compared to experimental measured value of 5.55 ton/ha/yr in case of similar biophysical watershed, Likhu Khola which is also tributary of same Trishuli River ${ }^{(24)}$, but the majority area of present watershed agreed with that rate of experimental field plots. Such erosion rate is considered as moderate in the mountainous areas where natural soil loss is high ${ }^{(17)}$. The most severe eroded areas with erosion rates shown in Table 2 and Fig. 3 were greater than 35 ton/ha/yr accounts for $0.013 \%$ of the total geographical area of the watershed. The slope of watershed ranges from nearly, less than $1^{\circ}$ to very steep slope, more than $30^{\circ}$.

Table 2. Soil loss estimation in Maheshkhola watershed.

\begin{tabular}{lccc}
\hline $\begin{array}{l}\text { Soil loss classes } \\
(\mathrm{t} / \mathrm{ha} / \mathrm{yr})\end{array}$ & $\begin{array}{c}\text { No of pixels (Npix) having } \\
\text { size }\left(50 \mathrm{~m}^{*} 50 \mathrm{~m}\right)\end{array}$ & $\begin{array}{c}\text { Area } \\
(\mathrm{ha})\end{array}$ & $\begin{array}{c}\text { Area } \\
(\%)\end{array}$ \\
\hline$<1$ & 46856 & 11714.00 & 46.257 \\
$1-5$ & 50196 & 12549.00 & 49.555 \\
$5-10$ & 3879 & 969.75 & 3.829 \\
$10-15$ & 218 & 54.50 & 0.215 \\
$15-20$ & 52 & 13.00 & 0.051 \\
$20-35$ & 80 & 20.00 & 0.079 \\
$>35$ & 13 & 3.25 & 0.013 \\
\hline
\end{tabular}

Soil loss in Maheshkhola watershed was estimated by physiographic land units in order to understand the degree of influence and role of physiographic landforms in accelerating erosion. The value of soil loss estimation was determined by map analysis process in ILWIS GIS and the result of soil loss by physiographic land units and its descriptive statistics were given in Table 3. Erosion rates were found highly correlated with the increasing slope of land units. It was evident by the fact that land units such as 11 and 12 having greater degree of slope less than $30^{\circ}$ and more than $30^{\circ}$ were found with the $33.0 \%$ of the total soil loss from each in the watershed. The average soil loss 
was found highest (3.62 t/ha) in land unit, 9cd characterized as depositional alluvial dissected fans where as the maximum (60.19 t/ha) soil loss was found highest in land unit 11a. Such land units were characterized by loamy boulder and loamy skeletal as dominant soil texture respectively.

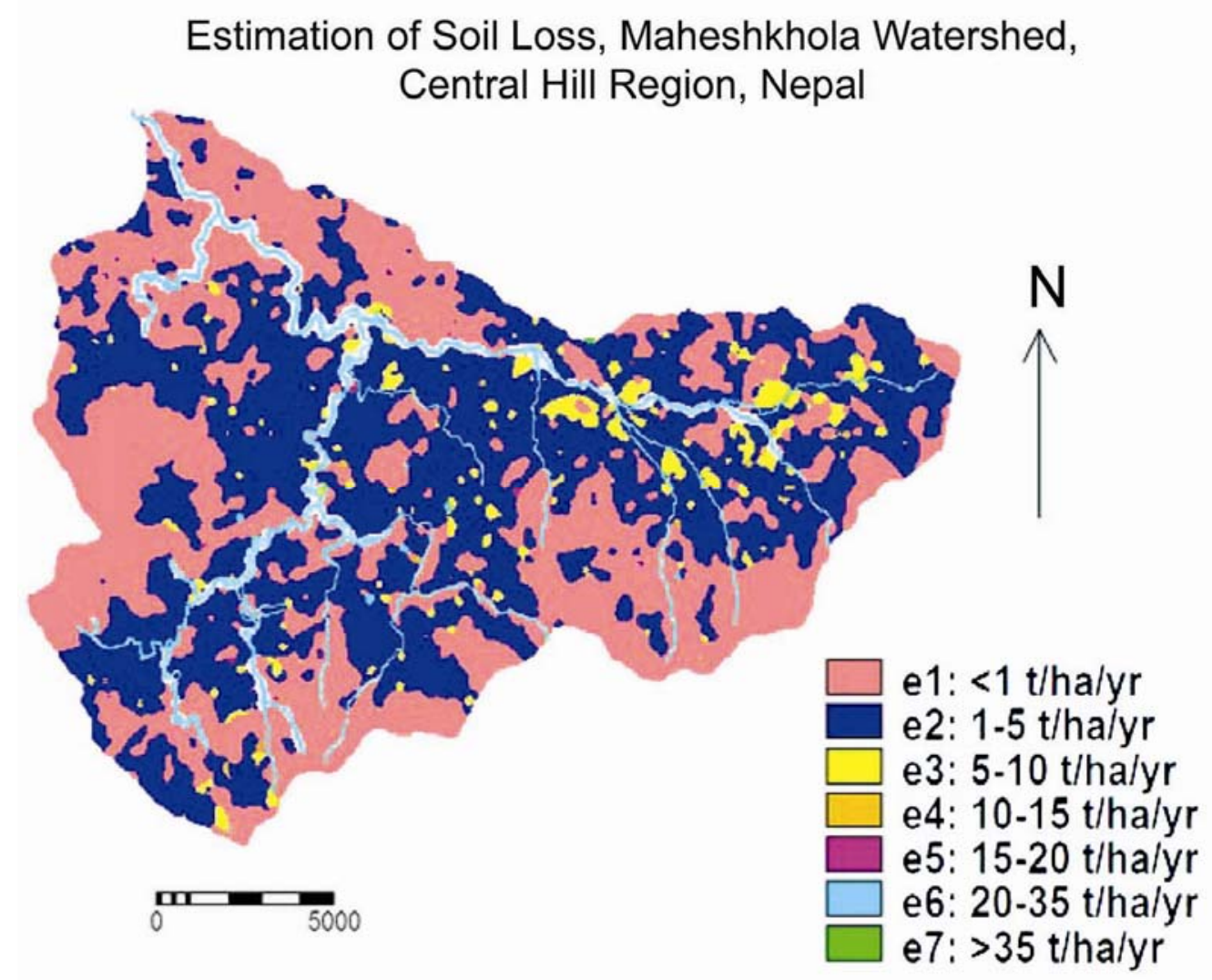

Fig. 3. Soil losses at different locations of Maheshkhola watershed, Central Hill Region, Nepal.

Soil loss in Maheshkhola watershed was estimated by land use and cover types in order to understand its role in determing erosion rate. The soil loss by land use and land cover types and its descriptive statistics were given in Table 4. Soil erosion rates were found highly correlated with the increasing exposure of land surface. It was supported by the fact that agriculture land sharing $61.53 \%$ of total land use land cover in the watershed, was contributing almost $90 \%$ of the total soil loss in the watershed. Similarly soil cliff/landslide and river sand areas were also considered as most influencing factor of soil erosion which were contributed $10.11 \mathrm{t} / \mathrm{ha}$ and $9.38 \mathrm{t} / \mathrm{ha}$ on an average, respectively. These three land use types were also characterized as land use types of maximum soil loss. 
The average annual soil lose from major land use/land cover types mentioned in Table 4 was compared with experimentally measured rates of Likhu Khola watershed having the similar mountainous characteristics and these rates were 0.48 ton/ha for irrigated terraces, 3.65 ton/ha for rainfed terraces, 1.86 ton/ha for grassland, 0.80 ton/ha for forested land, and 23.95 ton/ha for forest scrub and abandoned land ${ }^{(24)}$. The modelled

Table 3. Soil loss by physiographic land units.

\begin{tabular}{|c|c|c|c|c|c|c|c|}
\hline PHYSOIL & $\begin{array}{l}\text { Area in } \\
\text { ha }(\%)\end{array}$ & $\begin{array}{c}\text { Total } \\
\text { soil loss } \\
\text { (t/ha) }\end{array}$ & $\begin{array}{c}\% \text { of } \\
\text { total } \\
\text { soil loss } \\
\text { t/ha }\end{array}$ & $\begin{array}{c}\text { Average } \\
\text { soil loss } \\
\text { (t/ha) }\end{array}$ & $\begin{array}{l}\text { Standard } \\
\text { deviation } \\
\text { (Sd) of soil } \\
\text { loss (t/ha) }\end{array}$ & $\begin{array}{c}\text { Maximum } \\
\text { soil loss } \\
\text { (t/ha) }\end{array}$ & $\begin{array}{c}\text { Total no. of } \\
\text { pixels having } \\
\text { sized of } 50 \mathrm{~m} \\
\times 50 \mathrm{~m} \\
\end{array}$ \\
\hline River channel & 0.05 & 19.89 & 0.01 & 0.33 & 0.5 & 2.76 & 59 \\
\hline $\begin{array}{l}\text { Steeply to very } \\
\text { Steeply Slopping } \\
\text { Mountainous } \\
\text { Terrain(12) }\end{array}$ & 42.05 & 77101.24 & 33.35 & 1.87 & 2.8 & 34.53 & 45592 \\
\hline $\begin{array}{l}\text { Moderately to } \\
\text { Steeply sloping } \\
\text { Mountainous } \\
\text { Terrain(11) }\end{array}$ & 28.66 & 63878.02 & 27.63 & 2.18 & 2.0 & 25.32 & 31074 \\
\hline $\begin{array}{l}\text { Depositional } \\
\text { alluvial fans (9c) }\end{array}$ & 2.25 & 5634.66 & 2.44 & 2.34 & 2.2 & 23.55 & 2439 \\
\hline $\begin{array}{l}\text { Moderately to } \\
\text { Steeply sloping } \\
\text { Highly dissected } \\
\text { Mountaineous } \\
\text { Terrain (11a) }\end{array}$ & 25.37 & 78224.06 & 33.84 & 3.13 & 2.8 & 60.19 & 27506 \\
\hline $\begin{array}{l}\text { Ancient lake and } \\
\text { dissected } \\
\text { erosional river } \\
\text { terraces, tars (10b) }\end{array}$ & 0.03 & 83.22 & 0.04 & 2.37 & 2.1 & 8.16 & 35 \\
\hline $\begin{array}{l}\text { Depositional } \\
\text { alluvial } \\
\text { dissected } \\
\text { fans(9cd) }\end{array}$ & 1.60 & 6214.00 & 2.69 & 3.62 & 2.2 & 22.69 & 1731 \\
\hline
\end{tabular}

annual erosion rate in agriculture (3.55 ton/ha) confirmed with the experimentally measured rate of rainfed terraces ( $3.65 \mathrm{ton} / \mathrm{ha}$ ) but it is quite different in contrast to the erosion rate for agriculture ( $315 \mathrm{ton} / \mathrm{ha} / \mathrm{yr}$ ) estimated by using same model, RUSLE in Kalchi khola watershed of similar biophysical condition ${ }^{(25)}$. In case of forested land modelled rate ( 0.31 ton/ha) was slightly less than experimental value but quite different 
from Kalchi Khola of same land use ( 8 ton/ha/yr) whereas in case of grassland and abandoned land, it was significantly less in comparison of experimental value.

Table 4. Soil loss and land use/cover types.

\begin{tabular}{lcccccc}
\hline \multirow{2}{*}{ Land use/cover } & \multicolumn{7}{c}{ Soil loss (t/ha) } \\
\cline { 2 - 7 } & $\begin{array}{c}\text { Area } \\
(\%)\end{array}$ & $\begin{array}{c}\text { Soil loss } \\
(\%)\end{array}$ & $\begin{array}{c}\text { Average } \\
(\mathrm{t} / \mathrm{ha})\end{array}$ & $\begin{array}{c}\text { Sd } \\
\text { Agriculture }\end{array}$ & $\begin{array}{c}\text { Min. } \\
(\mathrm{t} / \mathrm{ha})\end{array}$ & $\begin{array}{c}\text { Max. } \\
(\mathrm{t} / \mathrm{ha})\end{array}$ \\
Forest & 91.53 & 89.96 & 3.5403 & 2.6 & 0.0275 & 60.1950 \\
Orchad & 9.79 & 1.33 & 0.3106 & 0.2 & 0.0025 & 1.5300 \\
Bushland & 0.04 & 0.01 & 0.0507 & 0.0 & 0.0075 & 0.1175 \\
Grashland & 14.69 & 1.54 & 0.2663 & 0.2 & 0.0025 & 2.6550 \\
Soil cliff & 0.50 & 0.02 & 0.0772 & 0.0 & 0.0050 & 0.2550 \\
Treeland & 0.94 & 4.45 & 10.1194 & 4.8 & 1.2675 & 34.5375 \\
River sand & 1.00 & 0.03 & 0.0675 & 0.0 & 0.0025 & 0.3000 \\
Dense mixed sal forest & 0.53 & 2.31 & 9.3874 & 7.1 & 0.1125 & 33.2925 \\
Dense mixed pine forest & 6.83 & 0.14 & 0.0502 & 0.0 & 0.0001 & 0.5500 \\
Dense mixed forest & 0.38 & 0.02 & 0.1058 & 0.1 & 0.0425 & 0.3875 \\
\hline
\end{tabular}

The results of erosion rates did not confirm with the values estimated by Jha and Poudel(25) by using same RUSLE model blaming that it overestimated due to some uncertainties of input parameters in mountainous terrain but confirmed with the values estimated by Shrestha(13) using RMMF model.

Table 5. Prioritization of areas for sustainable agriculture development.

\begin{tabular}{lll}
\hline Soil loss (ton/ha/yr)) & Class & Prioritization \\
\hline$<1$ & Very low & Low \\
$1-5$ & Low & low \\
$5-10$ & Moderate & Moderate \\
$10-15$ & High & High \\
$15-20$ & High & High \\
$20-35$ & High & High \\
$>35 \mathrm{t} / \mathrm{ha} / \mathrm{yr}$ & V high & V high \\
\hline
\end{tabular}

After assessment of soil loss severity over the entire watershed, it is essential to prioritizes the areas having high rate of soil erosion. In this context Table 5 has shown the prioritized areas where high rate of soil erosion estimated were observed. These areas are to be given high attention for watershed conservation and sustainability of land system. Based on severity of soil loss, land system conservation measures are to be adopted on 
more degraded areas for sustainable watershed management required for sustainable land use planning. The areas of steeply mountainous terrain having soil loss more than $35 \mathrm{t} / \mathrm{ha} / \mathrm{yr}$ has to be given highest priority for conservation management practices.

\section{References}

1. Nelson D 1980. A reconnaissance inventory of the major ecological land units and their watershed condition. Summary Report. Dept. of Soil Conservation and Watershed Management. UNDP, FAO FO: DP/NEP/74/020. Rome.

2. Joshi D, SP Pandey and RB Masky 1997. Status of Land Degradation in Nepal.

3. UNEP 2001 Nepal: State of the Environment in collaboration with MoPE/HMGN, SACEP, ICIMOD and NORAD, UNEP-Regional Resource Center for Asia and Passific.

4. Nakarmi G and PB Shah 2000. Soil nutrient losses through soil erosion in the middle hills of Nepal. In: Improved Soil Fertility Management for Sustainable Maize Production. BP Tripathi, NP Rajbhandari and JK Ransom (eds). Proc. of a workshop group meeting of the Hill Maize research project. Nepal Agricultural Research Council /HMRP / CIMMYT Nepal.

5. Wischmeier WH and DD Smith 1958. Rainfall energy and its relationship to soil loss. Transactions - American Geophysical Union 39: 285-291.

6. Wischmeier WH and DD Smith 1978. Predicting Rainfall Erosion Losses. Agricultural Handbook, USDA, Washington DC, USA. pp. 537.

7. Williams JR and HD Berndt 1977. Sediment yield prediction based on watershed hydrology, Trans. of the ASAE. 1100-1104.

8. Stocking M 1981. A working model for the estimation of soil loss suitable for underdeveloped areas. Development studies, occasional paper No. 15, University of East Anglia, Norwich (UK).

9. Renard KG, GR Foster, GA Weesies, DK McCool. and DC Yoder 1997. Predicting soil erosion by water: A guide to conservation planning with the revised Universal Soil Loss Equation (RUSLE), USDA Agricultural Handbook. USDA, Washington DC, USA. pp. 703.

10. SWCS 1993. User's guide. Revised Universal Soil Loss Equation, version 1.03. Soil and Water Conservation Society, Iowa, USA.

11. Flanagan DC, JC Ascough, MA Nearing and JM Laflen 2001. In: Landscape Erosion and Evolution Modeling, RS Harmon and W W Doe (Eds), Kluwer Academic Publishers, Norwell, MA, Water Erosion Prediction Project Model, p. 54.

12. Morgan RPC, JN Quinton, RE Smith, G Govers, JWA Poesen, K Auerswald, G Chisci, D Torri and ME Styczen 1998. The European Soil Erosion Model (EUROSEM): A dynamic approach for predicting sediment transport from fields and small catchments. Earth Surface Processes and Landforms. 23: 527-544.

13. Shrestha DP 1997. Assessment of soil erosion in the Nepalese Himalaya, a case study in Likhu Khola Valley, Middle Mountain Region International Institute for Aerospace Survey and Earth Sciences (ITC) 7500 AA Enschede, The Netherlands.

14. Andermann $C$ and R Gloagluen 2009. Estimation of erosion in tectonically active orogenies. Example from the Bhotekoshi catchment, Himalaya (Nepal), Int. J. Rem. Sens. 30 :12. 
15. Mandal UK 2011. Land Evaluation for Sustainable Land use Planning Using Remote Sensing and GIS Technology: A case study of Maheshkhola Watershed, Central Hill Region of Nepal, A Faculty Research, Research Division,University Grants Commission, Bhaktapur Kathmandu Nepal.

16. GON/DoS. 1996. Topograpgical Maps Sheet Index: 2784 04D, 2784 08B, 2785 01C, 2785 05A, 2785 01D, 2785 05B. Topographical Branch Survey Government of Nepal.

17. Morgan RPC 1986. Soil Erosion and Conservation. Longman Scientific and Technical, England ISBN 0-582-30158-0. pp. 298.

18. Morgan RPC, DDV Morgan and HJ Finney 1984. Stability of agricultural ecosystems: documentation of a simple model for soil erosion assessment. International Institute for Applied Systems Analysis Collaborative Paper CP-82-50

19. Morgan RPC 2001. A simple approach to soil loss prediction: A revised Morgan-MorganFinney model. Catena. 44: 305-322.

20. Renard KG and JR Freimund 1994. Using monthly precipitation data to estimate the R-factor in the revised USLE. J. Hydrol. 157: 287-306.

21. LRMP. 1986. Land System Report: The Soil Landscape of Nepal. Resources Mapping Project, Kenting Earth Sciences limited. Ottawa, Canada.

22. Renard KG, Foster GR, Weesies GA and Porter JP 1991. RUSLE: RevisedUniversal Soil Loss Equation. J. Soil Water Conserv. 46: 30-33.

23 Suriyaprasita M and DP Shrestha 2008. Deriving Land Use And Canopy Cover Factor From Remote Sensing And Field Data In Inaccessible Mountainous Terrain For Use In Soil Erosion Modelling. The International Archives of the Photogrammetry, Remote Sensing and Spatial Information Sciences. Vol. XXXVII. Part B7. Beijing .

24 Gerrard J and R Gardner 2002. Relationships between landsliding and land use in the Likhu Khola drainage basin, Middle Hills, Nepal. Moun. Res. Dev. 22: 48-55.

25. Jha MK and RC Paudel 2010. Erosion Predictions by Empirical Models in a Mountainous Watershed in Nepal. J. Spatial Hydrol. 10(1). 